\title{
Successful surgical treatment of supradiaphragmatic descending thoracic aorta coarctation with anomalous origin of truncus coeliacus
}

\author{
Dzyurman D. O. ${ }^{1}$, Radchenko M. P. ${ }^{1}$, Artemenko E. O. ${ }^{2}$, Serdenko B. B. ${ }^{2}$, \\ Rudenko N. M. ${ }^{2}$, Yemets I. M. ${ }^{1}$ \\ ${ }^{1}$ Ukrainian Children's Cardiac Center (Kyiv) \\ ${ }^{2}$ Shupyk National Medical Academy of Postgraduate Education (Kyiv)
}

\begin{abstract}
Middle aortic syndrome (MAS) is a segmental narrowing of the abdominal or distal descending thoracic aorta that is produced by congenital or by a number of acquired etiologies. MAS may be caused by Takayasu's or temporal arteritis (giant cell arteritides), neurofibromatosis, fibromuscular dysplasia, retroperitoneal fibrosis, mucopolysaccharidosis, and Williams syndrome, or congenital, ascribed to a developmental anomaly in the fusion and maturation of the paired embryonic dorsal aortas. Aim of this article is to present a clinical case of successful surgical treatment of middle aortic syndrome with anomalous truncus coeliacus (supradiaphragmatic origin and above coarctation segment) in 3-year-old patient. Material and methods. In this article we offer the case of a 3-year-old female patient with middle aortic syndrome (supradiaphragmatic coarctation of descending thoracic aorta) and anomalous truncus coeliacus. The final diagnosis was established with computed tomography. Computed tomography revealed quite unusual origin of truncus coeliacus (its origin was supradiaphragmatic and above coarctation). She has undergone a successful surgical treatment, end-to-end extended anastomosis technique with truncus coeliacus reimplantation. Results. Four months follow-up CT imaging showed no distortions and no restenosis at the anastomosis site. At 4 month follow-up examination patient was asymptomatic with no neurological dysfunction. Conclussion. End-toend extended anastomosisis is relatively safe technique and an effective method of treatment for atypical coarctation with significant postoperative reduction of arterial blood pressure.
\end{abstract}

Key words: middle aortic syndrome, end-to-end extended anastomosis, supradiaphragmatic coarctation of aorta.

Middle aortic syndrome (MAS) is a segmental narrowing of the abdominal or distal descending thoracic aorta that is produced by congenital or by a number of acquired etiologies. MAS may be caused by Takayasu's or temporal arteritis (giant cell arteritides), neurofibromatosis, fibromuscular dysplasia, retroperitoneal fibrosis, mucopolysaccharidosis, and Williams syndrome, or congenital, ascribed to a developmental anomaly in the fusion and maturation of the paired embryonic dorsal aortas [2]. Middle aortic syndrome (MAS) affects children and young adults, and it occurs in about $0.5 \%$ to $2.0 \%$ of all aortic coarctation cases [1]. Congenital, acquired, inflammatory and infectious etiologies have been described. In the majority of cases, there is a short, isolated or diffuse tubular narrowing of the descending thoracic and abdominal aorta, often accompanied by ostial stenosis or occlusion of the renal and visceral branches, which leads to renovascular hypertension and visceral ischemia [2, 3]. Surgical treatment should be considered in cases of uncontrollable hypertension, evidence of end-organ damage such as cardiac failure, progressive renal insufficiency or severe intermittent abdominal pain. Several surgical treatments for this condition have been reported, including bypass grafting, graft replacement, or patch angioplasty $[1,4]$. We report a successful surgical treatment case of a young female patient with middle aortic syndrome with a good late outcome. The peculiarity of this particular case is anomalous origin of truncus coeliacus (supradiaphragmatic origin and above coarctation segment).

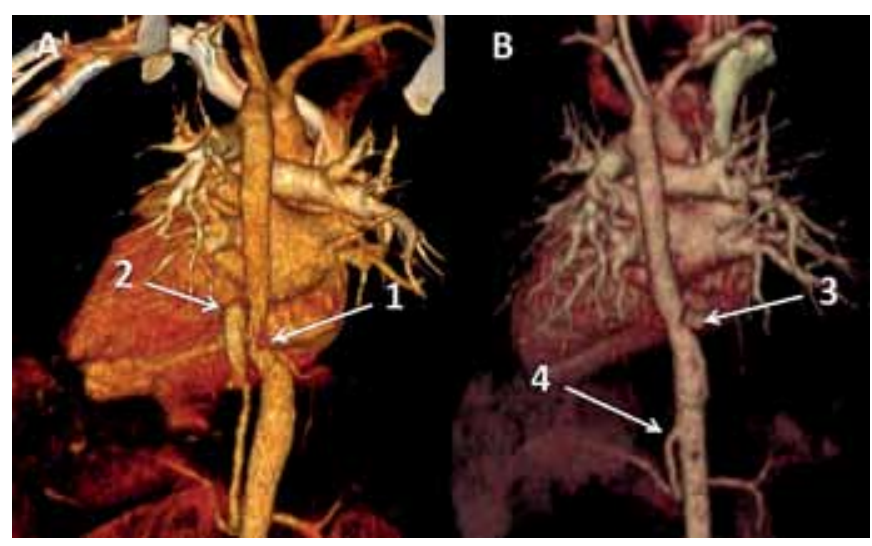

Fig. 1. Computed tomography. A - Before surgical treatment. $B$ - After surgical treatment 4 months follow-up.

1 - Supradiaphragmatic descending thoracic aorta coarctation site. 2 -Truncus coeliacus with severly dilated proximal segment. 3 - Anastomosis site 4 months later after coarctation surgical correction. 4 - Reimplanted truncus coeliacus (proximal dilated segment resected) 
The aim of this publication is to share quite rare clinical experience of successful surgical treatment of middle aortic syndrome (supradiaphragmatic aorta coarctation) by applying end to end extended anastomosis with truncus coeliacus reimplantation.

Material and methods. A 3-year-old female patient was examined because of hypertension and easy fatigability of the lower extremities. The femoral pulses were absent. Blood pressure, measured at admission, was $170 / 90$ $\mathrm{mmHg}$ at the brachial

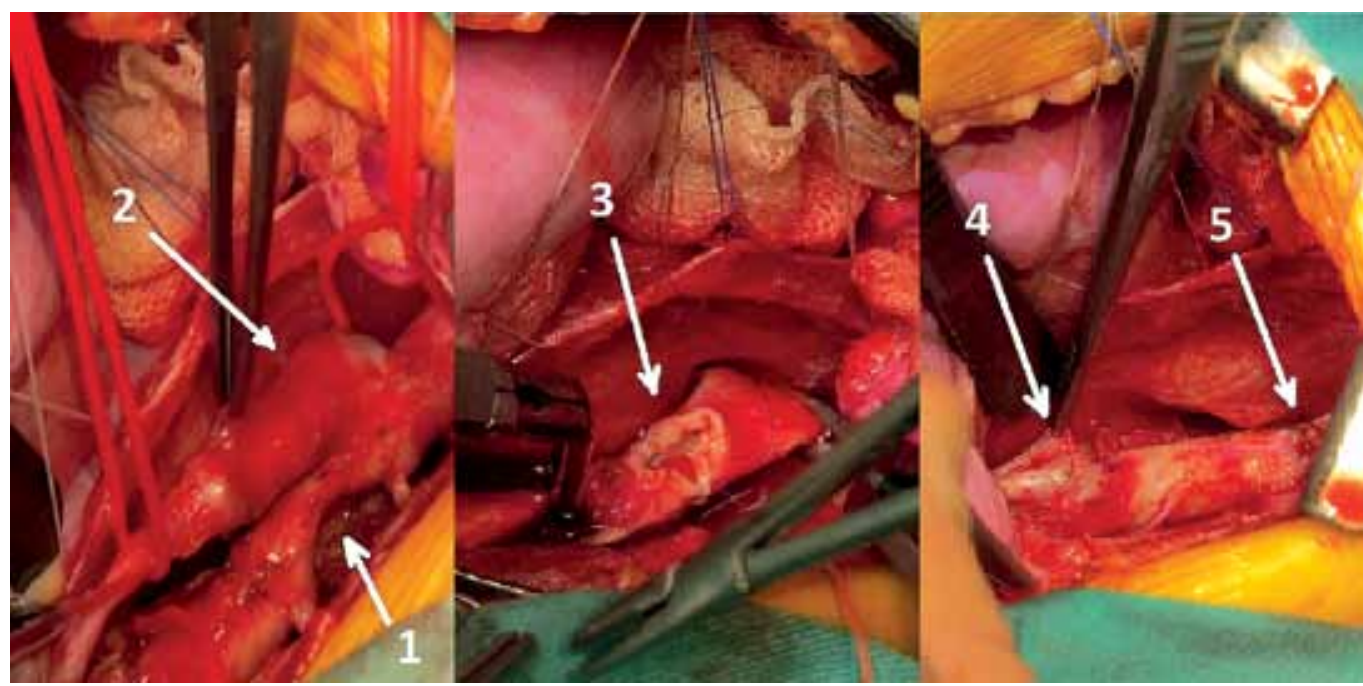

Fig. 2. Intraoperational photo: 1 - Supradiaphragmatic descending thoracic aorta coarctation. 2 - Truncus coeliacus with dilated proximal segment. 3 - Extended end-to-end anastomosis (sliding technique). 4 - Reimplanted truncus coeliacus (dilated proximal segment). 5 - Anastomosis artery. Patient's medical history included isolated, poorly controlled arterial hypertension despite pharmacotherapy (amlodipine, enalapril). The results of laboratory examinations were normal, including $\mathrm{C}$-reactive protein and procalcytonin. Transthoracic echocardiography showed a supradiaphragmatic narrowing of thoracic descending aorta with pressure gradient $64 \mathrm{mmHg}$, ascending aorta and aortic arch including its branches had no abnormalities, left ventricular ejection fraction $62 \%$, heart valves without morphological and functional abnormalities, slight left ventricle hypertrophy, no right or left ventricle dilatation. Patient was referred for computed tomography (CT) imaging for further diagnosis verification.

On CT the ascending aorta and aortic arch were normal. A severely stenotic segment $20-25 \mathrm{~mm}$ in length of descending aorta was visualized approximately $30-40 \mathrm{~mm}$ above diaphragma. Critical $(3-4 \mathrm{~mm})$ aortic coarctation was diagnosed strictly distal to truncus coeliacus rising.

Truncus coeliacus proximal segment was dilated. The aortic arch branches and renal arteries were normal. The collateral circulation was developed predominantly through 2-3 intercostal branches (Fig. 1A).

Surgery was performed through a left thoracotomy in $7^{\text {th }}$ intercostal space. Truncus coeliacus atypically arised at the supradiaphragmatic level of aorta above coarctation segment. Descending aorta clamped distal and proximal to coarctation. Truncus coeliacus clamped and dissected from aorta. Collateral arteries has been ligated, distal and proximal aorta mobilized. Coarctation of aorta has been resected and taken for histological examination. End-to-end extended anastomosis applied. Truncus coeliacus reimplanted to aorta distal to the anastomosis after resection of its dilated segment (Fig. 2). Direct pressure measurement revealed no gradient.

Results. Postoperative period was uneventful. After surgery patient received typical postcoarctation therapy with standard doses of hypertensive agents under arterial pressure control (brachial blood pressure of $110 / 70 \mathrm{mmHg}$ and femoral pressure of $105 / 65 \mathrm{mmHg}$ ).

On histological examination specimen is represented by transverse sections of 2 parallel vessels of different diameters, which are connected by a bridge of transversely directed structures of the media. Vessel with a larger diameter is aorta in the coarctation zone, and the 2nd vessel is truncus coeliacus. Both vessels have a corrugated inner elastic membrane, a fragmentation of elastic membranes, which in a smaller vessel have usual structure and direction, and in aorta - differently directed and sometimes sharply thinned. Smooth muscle cells and collagen fibers are disoriented due to collagen scaffold reinforcement and cell hypoxia. The adventitia of aorta is fibrous, truncus coeliacus tissue is friable and edematous.

At discharge from hospital pressure gradient on echo was $12 \mathrm{mmHg}$. Four-month follow-up computed tomographic (CT) examinations showed no distortions and no restenosis at the anastomosis site (Fig. 1B). At 4 month follow up she was asymptomatic with no neurological dysfunction.

Conclusion. End-to-end extended anastomosis is relatively safe technique and an effective method of treatment for atypical coarctation, with significant postoperative reduction of arterial blood pressure. This method required strict cooperation between radiologist and cardiac surgeon.

\section{References}

1. Rawan K. Rumman. Disease Beyond the Arch:A Systematic Review of Middle Aortic Syndrome in Childhood / Rawan K. Rumman, Cheri Nickel, Mina Matsuda- 
Abedini, Armando J. Lorenzo, Valerie Langlois, Seetha Radhakrishnan, Joao Amaral, Luc Mertens and Rulan S. Parekh // American Journal of Hypertension. July 2015. - Vol. 28 (7).

2. Yukihiro Matsuno, MD, PhD.A Successful Case of Ascending Aorta Abdominal Aorta Bypass for Middle Aortic Syndrome / Yukihiro Matsuno, MD, PhD, Yoshio Mori, MD, PhD, Yukio Umeda, MD, PhD, Matsuhisa Imaizumi, MD, PhD, and Hiroshi Takiya, MD, PhD // Vascular and Endovascular Surgery.- March 2009. Vol. 43, N 1, February. - P. 96-99.
3. Youkyung Lee. A Coarctation of the Distal ThoracicAorta with a Supradiaphragmatic Origin of the Celiacomesenteric Trunk: An Anatomic and Etiologic Description / Youkyung Lee, Whal Lee, Jae Hyung Park, Hyuk Ahn |// Cardiovasc Intervent Radiol. - 2010. - Vol. 33. - P. 1033-1035.

4. Mateusz Púslecki. Successful surgical treatment of a subtotal descending aortic occlusion / Mateusz Púślecki, Bartłomiej Perek, Sebastian Stefaniak, Andrzej Siniawski, Grzegorz Oszkinis, Marek Jemielity // CARDIOVASCULAR JOURNAL OF AFRICA. - March/April 2017. - Vol. 28, N 2.

\title{
Клінічний випадок успішного хірургічного лікування супрадіафрагмальної коарктації низхідної грудної аорти
}

\author{
Дзюрман Д. О. ${ }^{1}$, Радченко М. П. ${ }^{1}$, Артеменко Е. О. ${ }^{2}$, Серденко Б. Б. ${ }^{2}$, Руденко Н. М. ${ }^{2}$, Ємець І. М. ${ }^{1}$ \\ ${ }^{1}$ ДУ «Науково-практичний центр дитячої кардіології та кардіохірургії МОЗ України» (Київ) \\ ${ }^{2}$ Національна медична академія післядипломної освіти імені П. Л. Шупика (Київ)
}

Атипова коарктація аорти (супрадіафрагмальна) - сегментарне звуження абдомінальної або дистальної низхідної грудної аорти, яке може бути як вродженої етіології, так і набутої. Супрадіафрагмальна коарктація аорти може бути спричинена артеріїтом Такаясу (гігантськими клітинами артерітидами), нейрофіброматозом, фіброзном'язовою дисплазією, ретроперитонеальним фіброзом, мукополісахаридозом, синдромом Вільямса або виникати як наслідок аномалії розвитку в процесі злиття та дозрівання парних ембріональних дорсальних дужок аорти. В літературі зустрічаються описання клінічних випадків із супрадіафрагмальною коарктацією аорти, але особливість даного випадку полягає в аномальному відходженні черевного стовбура (по-перше - над діафрагмою, подруге - над коарктацією).

Мета статті - представити клінічний випадок успішного хірургічного лікування супрадіафрагмальної коарктації низхідної аорти з аномальним відходженням черевного стовбура у 3-річного пацієнта.

Матеріали та методи. У даній статті розглядається клінічний випадок супрадіафрагмальної коарктації низхідної аорти у 3-річного пацієнта. Остаточний діагноз встановлювали за допомогою комп'ютерної томографії. Було виконано успішне хірургічне лікування з використанням розширеного анастомозу «кінець в кінець» 3 реімплантацією truncus coeliacus, який мав атипове відходження.

Результати. Через чотири місяці спостереження на КТ-дослідженні не було виявлено рестенозу в ділянці анастомозу. Після 4-місячного спостереження пацієнт був безсимптомним, без ознак неврологічної дисфункції.

Висновок. Розширений анастомоз «кінець в кінець» $є$ відносно безпечною методикою та ефективним методом хірургічного лікування атипової супрадіафрагмальної коарктації низхідної аорти.

Ключові слова: розширений анастомоз «кінець в кінець», супрадіафрагмальна коарктація аорти. 